\title{
ANALISIS RELEVANSI MUATAN KURIKULUM PENDIDIKAN KIMIA DI PERGURUAN TINGGI DENGAN MUATAN KURIKULUM KIMIA BERBASIS K-13 DI SEKOLAH MENENGAH ATAS
}

\author{
Muhammad Risal, Muhammad Danial ${ }^{1}$, Ramlawati ${ }^{2}$ \\ ${ }^{1,2}$ Dosen Program Pascasarjana Universitas Negeri Makassar \\ Email: muhammad_risal91@yahoo.com
}

\begin{abstract}
ABSTRAK
Telah dilakukan penelitian tentang relevansi muatan profesional kurikulum pendidikan kimia di Jurusan Kimia FMIPA UNM dengan muatan kurikulum kimia berbasis K-13 di SMAN 17 Makassar dan SMAN 7 Makassar. Penelitian ini merupakan penelitian deskriptif kuantitatif dengan metode survei yang bertujuan untuk mengkaji muatan kurikulum kimia serta tingkat relevansi kedua muatan kurikulum kimia tersebut. Pengumpulan data dilakukan dengan mengkaji muatan kurikulum pendidikan kimia di Perguruan Tinggi dengan muatan kurikulum kimia berbasis K-13 di SMA serta melakukan wawancara kepada civitas akademik Program Studi Pendidika Kimia FMIPA UNM, Kepala Sekolah, Wakil Kepala Sekolah, dan para guru bidang studi kimia SMA. Penelitian ini menemukan bahwa terdapat 20 mata kuliah kimia yang wajib diprogram oleh mahasiswa Pendidikan Kimia dari semester I sampai semester VI serta terdapat 20 materi pokok mulia dari kelas X sampai kelas XII pada muatan kurikulum Kimia SMA bebasis K-13. Persentase kesesuaian muatan profesional Kurikulum Pendidikan Kimia FMIPA UNM terhadap materi pokok Kimia SMA sebesar 95\%, sementara persentase kesinambungan materi pokok Kimia SMA dengan mata kuliah sebesar 100\%, Persentase muatan profesional Kurikulum Pendidikan Kimia di Perguruan Tinggi yang tidak masuk dalam muatan Kurikulum Kimia SMA berbasis K-13 adalah sebesar 5\%, sehingga bisa disimpulkan bahwa kedua muatan kurikulum kimia tersebut memiliki tingkat kerelevanan dengan kategori sangat tinggi.
\end{abstract}

Kata kunci: Analisis Relevansi, Muatan Kurikulum Kimia Berbasis K-13, Muatan Profesional Kurikulum PSPK.

\begin{abstract}
The study had been conducted on the relevance of Chemistry education curriculum professional contents in Chemistry Department of Mathematics and Natural Science Faculty of State University of Makassar and Chemistry curriculum contents based on 2013 Curriculum in SMAN 17 Makassar and SMAN 7 Makassar. The research was descriptive quantitative research with survey method which aimed to review Chemistry curriculum contents and the relevance level of both Chemistry curriculum contents. The data were collected by reviewing Chemistry education curriculum contents in University and Chemistry curriculum contents based on 2013 Curriculum in Senior High School and by conducting interview to academic community of Chemistry Education Study Program of Mathematics and Natural Science Faculty of State University of Makassar, principals, vice principals, and Chemistry teachers of Senior High School. The research discovered that there were 20 of Chemistry Courses that must be programmed by the students of Chemistry Education from the first semester to the fourth semester and there were 20 subject matters from class $X$ to
\end{abstract}


class XII in Chemistry curriculum contents based on 2013 Curriculum in Senior High School. The percentage of the relevance of Chemistry curriculum contents of Chemistry Education of Mathematics and Natural Science Faculty of State University of Makassar toward Chemistry subject matters in Senior High School was 95\%; whereas, the percentage of the continuity of Chemistry subject matters in Senior High School and Chemistry courses was $100 \%$. The percentage of Chemistry curriculum contents of Chemistry Education in University which did not include in Chemistry curriculum contents based on 2013 Curriculum in Senior High School was 5\%. Therefore, the conclusion is both Chemistry curriculum contents have relevance level with very high category.

Keywords: Relevance Analysis, Chemistry Curriculum Contents Based on 2013 Curriculum, Chemistry Curriculum Contents Based on PSPK

\section{PENDAHULUAN}

Berkembangnya potensi peserta didik banyak dipengaruhi oleh kompetensi guru, olehnya itu untuk menghasilkan peserta didik sangat diperlukan guru yang berkompeten. Hasil uji kompetensi guru adalah 44,5 padahal nilai rata-rata yang diharapkan adalah 70 (berdasarkan hasil uji kompetensi guru pada tahun 2012 terhadap 460.000 guru), di sisi yang lain Indonesia menempati posisi 40 dari 40 negara pada pemetaan The Learning Curve-Pearson (hasil pemetaan aksen dan mutu pendidik pada tahun 2013 dan 2014), dan hasil pemetaan oleh universitas pada tahun 2013 tentang mutu pendidikan tinggi, Indonesia menempati posisi 49 dari 50 negara (Baswedan, 2014).

Sallis dalam Syarifuddin (2002), menyebutkan bahwa kondisi yang menyebabkan rendahnya mutu pendidikan dapat berasal dari berbagai macam sumber, yaitu miskinnya perancangan kurikulum, ketidakcocokan pengelolaan gedung, lingkungan kerja yang tidak kondusif, ketidaksesuaian sistem dan prosedur (manajemen), tidak cukupnya jam pelajaran, kurangnya sumber daya, dan pengadaan staf. Salah satu penyebab rendahnya kualitas pendidikan di Indonesia adalah rendahnya kualitas guru
(Baswedan, 2014). Keadaan guru di Indonesia masih menjadi perhatian. Kebanyakan guru termasuk guru-guru kimia belum memiliki profesionalisme yang memadai untuk menjalankan tugasnya sebagaimana disebutkan dalam pasal 39 UU No. 20/2003 yaitu merencanakan pembelajaran, melaksanakan pembelajaran, menilai hasil pembelajaran, melakukan pembimbingan, melakukan pelatihan, melakukan penelitian dan melakukan pengabdian masyarakat.

Adams \& Decey dalam Usman (2003), menyatakan bahwa hampir semua usaha reformasi pendidikan, seperti pembaruan kurikulum dan penerapan metode mengajar baru, akhirnya bergantung kepada guru. Tanpa mereka tidak mungkin siswa menguasai bahan pelajaran dan strategi pembelajaran, tanpa mereka tidak mungkin dapat mendorong siswa untuk belajar secara sungguh-sungguh. Guna mencapai prestasi yang tinggi, maka segala upaya peningkatan mutu pendidikan tidak akan mencapai hasil maksimal tanpa guru. Dalam Undang-undang Republik Indonesia nomor 14 Tahun 2005 tentang guru dan dosen, dijelaskan bahwa kompetensi adalah seperangkat pengetahuan, keterampilan, dan perilaku yang harus dimiliki, dihayati, dan dikuasi oleh guru 
atau dosen dalam melaksanakan tugas keprofesionalan, Undang-undang tersebut juga menegaskan bahwa Guru dan Dosen menjadi titik fokus perhatian upaya peningkatan kualitas pendidikan di tanah air. Dalam Undang-undang Nomor 19 Tahun 2005 Tentang Standar Nasional Pendidikan disebutkan bahwa kompetensi guru meliputi empat jenis, yaitu: kompetensi pedagogik, kompetensi kepribadian, kompetensi sosial, dan kompetensi profesional.

Menurut Oemar dalam Sukiman (2015) guru profesional adalah guru yang memiliki sejumlah kompetensi yang dituntut agar guru tersebut mampu melaksanakan tugasnya dengan sebaikbaiknya. Kompetensi-kompetensi guru tersebut dapat ditinjau dari berbagai segi tanggung jawab guru, fungsi, dan peranan mereka.

Berbagai upaya yang telah dilakukan untuk meningkatkan kompetensi guru, namun satu hal yang perlu di perhatikan dalam meningkatkan kompetensi guru adalah memperbaiki kebijakan yang diterapkan di Perguruan Tinggi di mana guru mengenyam pendidikan, salah satu kebijakan yang perlu diperhatikan adalah kurikulum, hal ini di kuatkan oleh Juangsih (2014) yang menyatakan bahwa LPTK merupakan salah satu kunci berhasil atau tidaknya pendidikan di Indonesia. LPTK memiliki tugas pokok untuk mendidik calon-calon guru Taman Kanak-kanak hingga Perguruan Tinggi sehingga perlu dilakukan perbaikan untuk menghasilkan lulusan yang berkualitas, misalnya pembenahan kurikulum dalam hal ini kurikulum LPTK harus dirancang sesuai dengan kebutuhan pasar. Karakteristik kurikulum yang baik adalah yang mampu memaksimalkan pengembangan potensi diri, bisa digunakan untuk semua karakter, membangun pemahaman sosial, pengembangan pengalaman, sesuai tujuan pendidikan, memanfaatkan pengalaman belajar yang efektif dan sumber daya yang dibutuhkan (Hussain, et al., 2011).

Universitas Negeri Makassar (UNM) merupakan salah satu kampus yang dikenal dengan pencetak guru terbesar di kawasan Timur Indonesia. Dengan identitasnya sebagai kampus Oemar Bakrie tentu sudah banyak menelorkan tenaga pendidik yang tersebar di berbagai daerah di seluruh Indonesia, hal ini menuntut pihak UNM untuk mempetahankan predikat tersebut dan selalu melakukan perbaikan sehingga mampu memenuhi kebutuhan masyarakat dalam dunia pendidikan, salah satu aspek yang perlu diperhatikan adalah merancang kurikulum yang sesuai dengan kurikulum nasional dan kebutuhan masyarakat (Bustan, 2013), hal ini dikuatkan oleh Lozano \& Mary (2013) yang menyatakan bahwa salah satu tujuan analisis kurikulum adalah untuk menilai secara sitematis bagaimana kurikulum Universitas memberikan konstribusi terhadap pelaksanaan kurikulum yang ada disekolah dilihat dari segi keluasan dan kedalaman materi. Primrose \& Chabaya (2013) juga menyebutkan bahwa penyusunan kurikulum Perguruan Tinggi harus sesuai dengan kebutuhan masyarakat dan mampu menjawab tantangan masa depan.

Syahrial, et al. (2010); Zaura \& Suryawati (2010), menyatakan bahwa dalam usaha menyempurnakan kurikulum setiap Program Studi Pendidikan, perlu dilakukan peninjauan terhadap kurikulum di sekolah-sekolah, menggali informasi dari lulusan yang sudah bekerja, serta masukan-masukan dari stake holder tentang lulusan yang diharapkan saat ini. 
Salsabila (2013) juga menyatakan bahwa, pengembangan kurikulum harus relevan dengan tuntutan dunia pekerjaan sesuai dengan kebutuhan dan karakteristik masyarakat dalam dunia kerja.

Berdasarkan latar belakang tersebut maka perlu dilakukan Analisis Relevansi Muatan Kurikulum Pendidikan Kimia di Perguruan Tinggi dengan Muatan Kurikulum Kimia Berbasis K-13 di Sekolah Menengah Atas.

\section{METODE PENELITIAN}

Jenis penelitian ini adalah penelitian deskriptif kuantitatif dengan metode survei. Data yang diperlukan dalam penelitian ini dikumpulkan dengan melakukan pengkajian terhadap muatan kurikulum Progran Studi Pendidikan Kimia yang ada di FMIPA UNM yang relevan dengan muatan Kurikulum Kimia Sekolah berbasis K-13 khususnya di SMAN 7 Makassar dan SMAN 17 Makassar berdasarkan hubungan matriks muatan Kurikulum Pendidikan Kimia di FMIPA UNM dan muatan Kurikulum Kimia berbasis K-13 di SMA. Untuk melengkapi data yang diperlukan, digunakan analisis matriks, wawancara, dan dokumentasi. Data yang terkumpul dianalisis dengan teknik deskriptif kuantitatif kemudian dikonversi dan disimpulkan ke dalam bentuk kualitatif. Teknik analisis data dalam penelitian ini berupa analisis matriks hubungan muatan Kurikulum Kimia Berbasis K-13 di SMA dengan muatan Kurikulum Pendidikan Kimia di FMIPA UNM.

\section{HASIL DAN PEMBAHASAN}

1. Gambaran Muatan Kurikulum Pendidikan Kimia di Perguruan Tinggi

Muatan profesinal kurikulum kimia terdapat 20 mata kuliah kimia yang wajib diprogramkan di FMIPA UNM oleh mahasiswa Pendidikan Kimia yang terdistribusi dari semester I sampai dengan semester VI. Gambaran muatan profesional kurikulum Pendidikan Kimia FMIPA UNM disajikan pada Tabel 4.1

Tabel 4.1 Gambaran Muatan Profesional Kurikulum Pendidikan Kimia FMIPA UNM

\begin{tabular}{|c|c|c|c|}
\hline $\begin{array}{l}\text { Sem } \\
\text { ester }\end{array}$ & $\begin{array}{c}\text { Mata } \\
\text { Kulia } \\
\text { h }\end{array}$ & SKS & Deskripsi Mata Kuliah \\
\hline I & $\begin{array}{l}\text { Kimia } \\
\text { Dasar }\end{array}$ & $\begin{array}{c}3 \\
(1)\end{array}$ & $\begin{array}{l}\text { Struktur Atom; Sistem } \\
\text { Periodik, Struktur Molekul; } \\
\text { Stokiometri; Termokimia; } \\
\text { Larutan; Elektrokimia; } \\
\text { Elektron; Kinetika kimia; } \\
\text { Kimia karbon; dan Biokimia }\end{array}$ \\
\hline \multirow[t]{2}{*}{ II } & $\begin{array}{l}\text { Kimia } \\
\text { Dasar } \\
\text { Lanjut }\end{array}$ & $\begin{array}{c}3 \\
(1)\end{array}$ & $\begin{array}{l}\text { Hukum pertama } \\
\text { termodinamika; Hukum kedua } \\
\text { termodinamika; Tetapan } \\
\text { kesetimbangan, } \\
\text { kesetimbangan dan energi } \\
\text { bebas, hubungan Kp, Kc dan } \\
\text { Kp, kesetimbangan } \\
\text { Heterogen; Asas Le Chatelier, } \\
\text { perhitungan kesetimbangan, } \\
\text { kesetimbangan dalam larutan; } \\
\text { Hukum Roult dan sifat } \\
\text { kolegatif, larutan elektrolit } \\
\text { dan sifat-sifatnya; Hidrolisis, } \\
\text { pH larutan garam, larutan } \\
\text { buffer, titrasi asam basa; } \\
\text { Kimia koloid; Kinetika kimia; } \\
\text { Sel galvani, potensial sel, } \\
\text { potensial elektroda; } \\
\text { Persamaan Nernst, } \\
\text { elektrolisis, hukum Faraday; } \\
\text { Hidrogen, oksigen, nitrogen } \\
\text { dan fosfor; Golongan halogen, } \\
\text { golongan mulia, golongan } \\
\text { alkali, alkali tanah dan } \\
\text { transisi; Perubahan radio } \\
\text { aktif, transmutasi inti, } \\
\text { kestabilan inti; dan Reaksi fisi } \\
\text { dan fusi, energi ikatan inti. }\end{array}$ \\
\hline & $\begin{array}{l}\text { Pengel } \\
\text { olaan } \\
\text { Labora } \\
\text { torium } \\
\text { Kimia }\end{array}$ & 2 & \begin{tabular}{lrr} 
Keselamatan & kerja di lab; \\
Pertolongan & pertama pada \\
kecelakaan; & \multicolumn{2}{r}{ Teknik } \\
administrasi & laboratorium; \\
Peranan laboran & dalam \\
praktikum & kimia; & Pembuatan \\
larutan; & dan & Cara
\end{tabular} \\
\hline
\end{tabular}




\begin{tabular}{|c|c|c|c|}
\hline & & & $\begin{array}{l}\text { menggunakan alat-alat gelas } \\
\text { dan berbagai jenis alat } \\
\text { elektronik lainnya }\end{array}$ \\
\hline & $\begin{array}{l}\text { Kimia } \\
\text { Organi } \\
\text { k I }\end{array}$ & 3 & $\begin{array}{lr}\text { Perkembangan } & \text { struktur } \\
\text { molekul organik; Hibridisasi } \\
\mathrm{Sp}^{3}, \mathrm{Sp}^{2}, \mathrm{Sp} \text { dan } & \text { teori } \\
\text { resonansi; Teori asam basa, } \\
\text { gaya antara molekul; Alkana } \\
\text { dan siklo alkana; Konformasi } \\
\text { alkana dan siklo alkana; } \\
\text { Alkena dan alkuna; Senyawa } \\
\text { aromatik; Senyawa halogen } \\
\text { organik; Alkohol, fenol; } \\
\text { Alkohol,eter Aldehid dan } \\
\text { keton; Reaksi-reaksi pada } \\
\text { gugus karbonil; Asam } \\
\text { karboksilat; dan Turunan } \\
\text { asam karboksilat }\end{array}$ \\
\hline & $\begin{array}{l}\text { Kimia } \\
\text { Matem } \\
\text { atika }\end{array}$ & 2 & $\begin{array}{l}\text { Notasi Ilmiah dan angka } \\
\text { signifikan; Satuan SI dan } \\
\text { konversi; Logaritma; Linier } \\
\text { dan non linier; Kurva; Vektor; } \\
\text { Matriks; Deferensial; } \\
\text { Bilangan Kompleks; Deret; } \\
\text { Fungsi; dan Integral }\end{array}$ \\
\hline & $\begin{array}{l}\text { Kimia } \\
\text { Anorga } \\
\text { nik I }\end{array}$ & 2 & 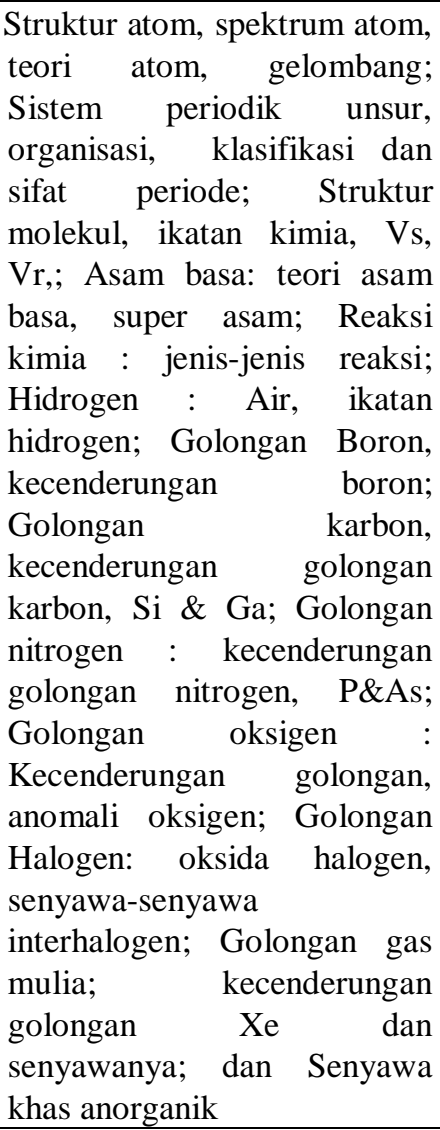 \\
\hline III & $\begin{array}{l}\text { Kimia } \\
\text { Analiti } \\
\text { k I }\end{array}$ & 3 & 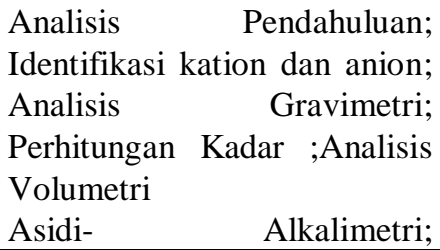 \\
\hline
\end{tabular}

\begin{tabular}{|c|c|c|}
\hline & & $\begin{array}{lrr}\begin{array}{l}\text { Perhitungan } \\
\text { cuplikan; }\end{array} \text { Asam } & \text { basa } \\
\text { Perhitungan } & \text { irgentometri; } \\
\text { Kompleksometri; } & \text { Proses; } \\
\text { Proses } & \text { analisis } \\
\text { Kompleksometri; } & \\
\begin{array}{l}\text { Oksidimetri; dan } \\
\text { Kuantitas redoks }\end{array} & \text { Analisis } \\
\end{array}$ \\
\hline $\begin{array}{l}\text { Kimia } \\
\text { Fisik I }\end{array}$ & 3 & $\begin{array}{l}\text { Konsep dasar kimia, } \\
\text { persamaan keadaan gas ideal; } \\
\text { Virial,isoterm, persamaan } \\
\text { keadaan gas tak ideal; } \\
\text { Termokimia, entalpi, } \\
\text { kapasitas, kalor, energi ikatan; } \\
\text { Hukum II entropi; Energi } \\
\text { bebas dan kesetimbangan; } \\
\text { Kesetimbangan homogen dan } \\
\text { heterogen; Kesetimbangan } \\
\text { reaksi Biokimia; Hukum fasa, } \\
\text { diagram fasa,komponen; } \\
\text { Diagram fasa 2 dan } 3 \\
\text { komponen; Potensial kimia } \\
\text { dan larutan ideal, fugasitas, } \\
\text { keaktifan; Hukum Roult, } \\
\text { Hukum Henry; Hukum Gibbs } \\
\text { Duhem dan sifat-sifat } \\
\text { koligatif larutan; Berbagai } \\
\text { jenis elektroda DGL dan } \\
\text { Persamaan Nernst; dan } \\
\text { Termodinamika dari DGL sel }\end{array}$ \\
\hline $\begin{array}{l}\text { Kimia } \\
\text { Anorga } \\
\text { nik II }\end{array}$ & 2 & $\begin{array}{l}\text { Ikatan Metalik; Ikatan ionik \& } \\
\text { metalurgi; Golongan alkali; } \\
\text { Gol. Alkali tanah; Golongan } \\
\text { 13; Golongan 14 dan 15; } \\
\text { Kimia; Unsur transisi; } \\
\text { Golongan 4; Golongan 5; } \\
\text { Golongan 6; Golongan } 7 \text { dan } \\
\text { 8; Golongan } 9 \text { \& 10; dan } \\
\text { Golongan } 11\end{array}$ \\
\hline $\begin{array}{l}\text { Kimia } \\
\text { Organi } \\
\text { k II }\end{array}$ & 3 & 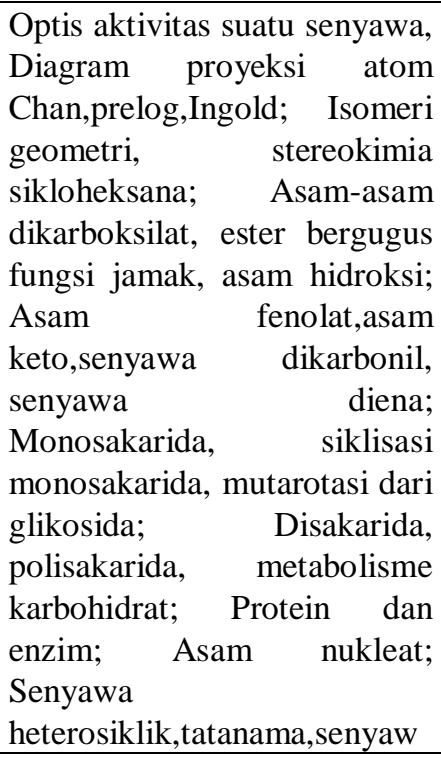 \\
\hline
\end{tabular}




\begin{tabular}{|c|c|c|c|}
\hline & & & $\begin{array}{l}\text { a heterosiklik lingkar enam } \\
\text { dengan } \\
\text { heteroatom,senyawa } \\
\text { heterosiklik lingkar enam; } \\
\text { Senyawa heterosiklik dengan } \\
\text { poliheteroatom, senyawa hasil } \\
\text { alam, hetero siklik; Lemak, } \\
\text { senyawa terpenoid, } \\
\text { poliketida; Senyawa } \\
\text { flavanoid, alkaloid, deteksi } \\
\text { dan pemurnian; dan } \\
\text { Hidrokarbon aromatik } \\
\text { polisiklik, naftalen, naftol, } \\
\text { antrasena, fenantren. }\end{array}$ \\
\hline & $\begin{array}{l}\text { Kimia } \\
\text { Analiti } \\
\text { k II }\end{array}$ & 3 & 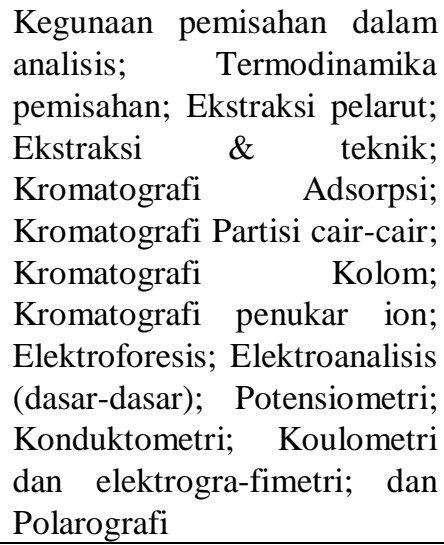 \\
\hline IV & $\begin{array}{l}\text { Kimia } \\
\text { Fisik II }\end{array}$ & 3 & $\begin{array}{l}\text { Model gas ideal, distribusi } \\
\text { kecepatan moleku dan } \\
\text { macam-macam kecepatan } \\
\text { rata-rata; Tumbukan molekul, } \\
\text { jarak bebas rata-rata; Gejala } \\
\text { perpindahan dalam gas, } \\
\text { viskositas gas; Pengertian laju } \\
\text { reaksi, persamaan laju dan } \\
\text { konsep orde reaksi; Penentuan } \\
\text { persamaan laju reaksi; } \\
\text { Pengaruh suhu pada laju } \\
\text { reaksi, konsep energi } \\
\text { pengaktifan; Mekanisme } \\
\text { reaksi sederhana, reaksi } \\
\text { reversibel, berurutan dan } \\
\text { paralel, pendekatan keadaan } \\
\text { tetap; Reaksi unimolekuler, } \\
\text { reaksi kompeks; Kinetika } \\
\text { asam basa; Katalis enzim dan } \\
\text { reaksi koenzim; Mekanisme } \\
\text { polimerisasi, kondensasi } \\
\text { bertahap dan radikal bebas; } \\
\text { Hukum-hukum fotokimia, } \\
\text { hasil kuantum, fluoresensi dan } \\
\text { fosforesensi; Kinetika } \\
\text { fotokimia, kinetika } \\
\text { penguraian HI dan sintesis } \\
\text { HBr; Fotosintesis; Hantaran } \\
\text { listrik dan bilangan hantaran, } \\
\text { sel elktrolitik, hukum } \\
\text { Faraday; Kemobilan listrik }\end{array}$ \\
\hline
\end{tabular}

\begin{tabular}{|c|c|c|}
\hline & & $\begin{array}{l}\text { dan kekuatan ion; Aplikasi } \\
\text { dari pengkuran daya hantar; } \\
\text { Viskositas dan penentuan } \\
\text { koefisien viskositas; dan } \\
\text { Difusi dan penentuan } \\
\text { koefisien difusi. Sedimentasi }\end{array}$ \\
\hline $\begin{array}{l}\text { Kimia } \\
\text { Anorga } \\
\text { nik } \\
\text { Fisik }\end{array}$ & 2 & 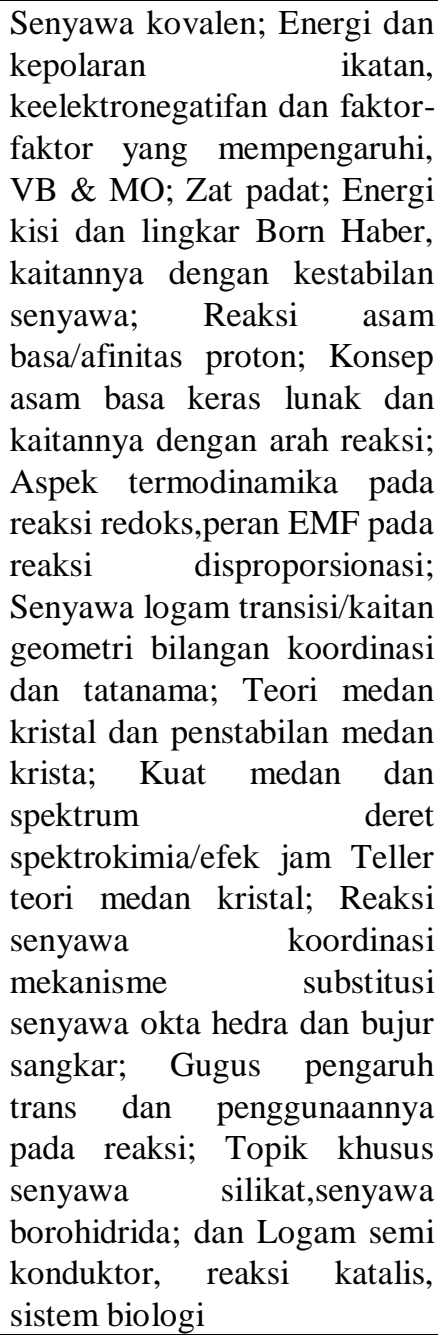 \\
\hline $\begin{array}{l}\text { Kimia } \\
\text { Organi } \\
\text { k III }\end{array}$ & 2 & \begin{tabular}{lll} 
Konsep & dasar & \multicolumn{2}{c}{ mekanisme } \\
reaksi; Mekanisme & reaksi \\
substitusi; Mekanisme & reaksi \\
eliminasi; Mekanisme & reaksi \\
adisi; Mekanisme & reaksi \\
redoks; Mekanisme & reaksi \\
radikal bebas; Mekanisme \\
reaksi penataan ulang; dan \\
Mekanisme & reaksi \\
polimerisasi & \\
\end{tabular} \\
\hline $\begin{array}{l}\text { Biokim } \\
\text { ia }\end{array}$ & 3 & $\begin{array}{l}\text { Pengantar; } \\
\text { Enzim dan mekanismenya; } \\
\text { Metabolisme karbohidrat; } \\
\text { Rantai pengangkut elektron } \\
\text { dan fotofosforikasi; } \\
\text { Fotosintesis; Metabolisme } \\
\text { lipid; Metabolisme protein; } \\
\text { Dasar-dasar asam nukleat; } \\
\text { dan Replikasi, transkripsi dan } \\
\text { translasi }\end{array}$ \\
\hline
\end{tabular}




\begin{tabular}{|c|c|c|c|}
\hline & $\begin{array}{l}\text { Ikatan } \\
\text { Kimia }\end{array}$ & 2 & $\begin{array}{l}\text { Teori Atom dan aspek } \\
\text { eksperimental dari teori } \\
\text { kuantum; Dasar-dasar teori } \\
\text { kuantum dan atom hidrogen; } \\
\text { Ikatan kovalen; Ikatan Ion; } \\
\text { Ikatan lain-lain; dan Senyawa } \\
\text { kompleks }\end{array}$ \\
\hline \multirow{3}{*}{ V } & $\begin{array}{l}\text { Kimia } \\
\text { Analisi } \\
\mathrm{s} \\
\text { Instru } \\
\text { men }\end{array}$ & 2 & $\begin{array}{l}\text { Perbedaan metode konvensasi } \\
\text { dan metode instrumental; } \\
\text { Kimia analisis instrumen } \\
\text { secara umum; Signal dan } \\
\text { Noise; Sepektroskopi Uv dan } \\
\text { UV-Vis; Spektroskopi IR; } \\
\text { Fotometri nyala (AAS); } \\
\text { Kekurangan dan kelebihan } \\
\text { fotometri nyala (AA); HPLC; } \\
\text { Elektrokimia secara umum; } \\
\text { Potensiometri; } \\
\text { Elektrografvimetri; } \\
\text { Koulometri; dan Plarografi. }\end{array}$ \\
\hline & $\begin{array}{l}\text { Kimia } \\
\text { Inti } \\
\text { dan } \\
\text { Radiok } \\
\text { imia }\end{array}$ & 2 & $\begin{array}{l}\text { Pengenalan Kimia Inti dan } \\
\text { Radiokimia; Sifat-sifat Inti; } \\
\text { Tipe Peluruhan Radioaktif; } \\
\text { Model-model Inti; Reaksi } \\
\text { Inti; Kinetika Reaksi Inti; } \\
\text { Interaksi Radiasi dengan } \\
\text { Materi; Instrumentasi } \\
\text { Radiokimia; Analisa Aktivasi } \\
\text { Inti; dan Penggunaan } \\
\text { Radioisotop }\end{array}$ \\
\hline & $\begin{array}{l}\text { Kimia } \\
\text { Pangan }\end{array}$ & $\begin{array}{l}3( \\
1)\end{array}$ & $\begin{array}{l}\text { Pengantar kimia pangan; Air } \\
\text { dalam bahan pangan; Protein; } \\
\text { Karbohidrat; Lemak; Reaksi } \\
\text { kimia yang menyertai; } \\
\text { Perubahan KOH, Lipid, } \\
\text { protein, analisis protein dan } \\
\text { lipid; Vitamin; Mineral; } \\
\text { Pengolahan vitamin larut } \\
\text { air/lemak; Cita rasa/Flavor; } \\
\text { Zat aditif makanan; Senyawa } \\
\text { beracun/toksik bahan pangan; } \\
\text { dan Warna }\end{array}$ \\
\hline VI & $\begin{array}{l}\text { Kimia } \\
\text { Lingku } \\
\text { ngan }\end{array}$ & 2 & $\begin{array}{lr}\text { Manusia dan } r & \text { Lingkungan; } \\
\text { Pencemaran } & \text { Udara; } \\
\text { Lingkungan air; Lingkungan } \\
\text { tanah ; Proses perubahan } \\
\text { bahan kimia } & \text { dalam } \\
\text { lingkungan hidup; Siklus } \\
\text { beberapa bahan kimia; Dasar- } \\
\text { dasar pengelolaan limbah air; } \\
\text { Plastik; Zat Aditif; Sanitasi } \\
\text { lingkungan; } \\
\text { penjernihan air; Pengolahan } \\
\text { limbah; Parameter kualitas } \\
\text { air; dan Analisis mengenai } \\
\text { dampak lingkungan. }\end{array}$ \\
\hline
\end{tabular}

Berdasarkan hasil wawancara yang dilaksanakan di Jurusan Kimia FMIPA UNM, SMA 17 Makassar, dan SMA 7 Makassar, beberapa narasumber menyarankan agar muatan Kurikulum Pendidikan Kimia FMIPA UNM dikurangi namun jumlah SKS ditambah sehingga bisa lebih dimaksimalkan, Kurikulum Pendidikan Kimia lebih disesuaikan lagi dengan pengguna lulusan, sarana prasarana dilengkapi, pengajar di bidang pendidikan agar ditambah kuotanya, pada intinya semua masukan memberikan harapan besar agar Muatan Kurikulum Program Studi Pendidikan Kimia dirancang sedemikian rupa sehingga memberikan bekal dasar yang cukup kepada alumni sehingga mampu memenuhi kebutuhan pengguna lulusan.

2. Gambaran Muatan KurikulumKimia SMA Berbasis K-13 di Sekolah Menengah Atas.

Muatan kurikulum Kimia SMA berbasis K-13 adalah muatan kurikulum K13 revisi yang mulai digunakan tahun akademik 2016/2017. Muatan kurikulum Kimia SMA berbasis K-13 memiliki dua Kompetensi Dasar yaitu Kompetensi Dasar Pengetahuan dan Kompetensi Dasar Keterampilan. Berdasarkan Kompetensi Dasar Pengetahuan dan Kompetensi Dasar Keterampilan, diperoleh 20 materi pokok Kimia yang terdistribusi dari kelas $\mathrm{X}$ sampai kelas XII. Gambaran muatan kurikulum Kimia SMA berbasis K-13 disajikan pada Tabel 4.2

Tabel 4.2 Gambaran Muatan Kurikululum Kimia SMA Berbasis K-13

\begin{tabular}{|c|c|c|}
\hline $\begin{array}{c}\text { Materi } \\
\text { Pokok }\end{array}$ & $\begin{array}{c}\text { Kompetensi Dasar } \\
\text { (Pengetahuan) }\end{array}$ & $\begin{array}{c}\text { Kompetensi } \\
\text { Dasar } \\
\text { (Keterampilan) }\end{array}$ \\
\hline \multicolumn{3}{|c|}{ KELAS X } \\
\hline Hakikat & 3.1 Menjelaskan & 4.1 Menyajikan \\
\hline
\end{tabular}




\begin{tabular}{|c|c|c|}
\hline $\begin{array}{l}\text { dan } \\
\text { Peran } \\
\text { Kimia } \\
\text { dalam } \\
\text { kehidupa } \\
\text { n serta } \\
\text { Metode } \\
\text { Ilmiah }\end{array}$ & $\begin{array}{l}\text { metode ilmiah, } \\
\text { hakikat ilmu } \\
\text { Kimia, } \\
\text { keselamatan } \\
\text { dan keamanan } \\
\text { di laboratorium, } \\
\text { serta peran } \\
\text { kimia dalam } \\
\text { kehidupan }\end{array}$ & $\begin{array}{l}\text { hasil } \\
\text { rancangan dan } \\
\text { hasilpercobaan } \\
\text { ilmiah }\end{array}$ \\
\hline \multirow{3}{*}{$\begin{array}{l}\text { Struktur } \\
\text { Atom dan } \\
\text { Tabel } \\
\text { Periodik }\end{array}$} & 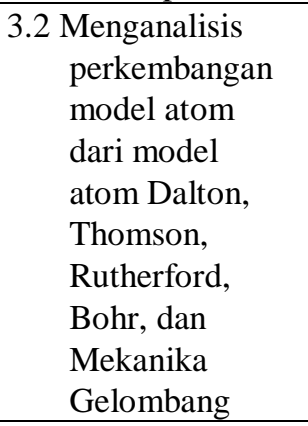 & $\begin{array}{l}\text { 4.2 } \text { Menjelaskan } \\
\text { fenomena } \\
\text { alam atau hasil } \\
\text { percobaan } \\
\text { menggunakan } \\
\text { model atom }\end{array}$ \\
\hline & $\begin{array}{l}\text { 3.3 Menjelaskan } \\
\text { konfigurasi } \\
\text { elektron dan } \\
\text { pola konfigurasi } \\
\text { elektron terluar } \\
\text { untuk setiap } \\
\text { golongan dalam } \\
\text { tabel periodik }\end{array}$ & \begin{tabular}{|l}
4.3 Menentukan \\
letak suatu \\
unsur dalam \\
tabel periodik \\
berdasarkan \\
konfigurasi \\
elektron
\end{tabular} \\
\hline & $\begin{array}{l}\text { 3.4 Menganalisis } \\
\text { kemiripan sifat } \\
\text { unsur dalam } \\
\text { golongan dan } \\
\text { keperiodikanny } \\
\text { a }\end{array}$ & $\begin{array}{l}\text { 4.4 Menyajikan } \\
\text { hasil analisis } \\
\text { data-data } \\
\text { unsur dalam } \\
\text { kaitannya } \\
\text { dengan } \\
\text { kemiripan } \\
\text { dan sifat } \\
\text { keperiodikan } \\
\text { unsur } \\
\end{array}$ \\
\hline \multirow[t]{2}{*}{$\begin{array}{l}\text { Ikatan } \\
\text { Kimia }\end{array}$} & $\begin{array}{l}\text { 3.5 Membandingkan } \\
\text { ikatan ion, } \\
\text { ikatan kovalen, } \\
\text { ikatan kovalen } \\
\text { koordinasi, dan } \\
\text { ikatan logam } \\
\text { serta kaitannya } \\
\text { dengan sifat zat }\end{array}$ & $\begin{array}{l}\text { 4.5 Merancang } \\
\text { dan } \\
\text { melakukan } \\
\text { percobaan } \\
\text { untuk } \\
\text { menunjukkan } \\
\text { karakteristik } \\
\text { senyawa ion } \\
\text { atau senyawa } \\
\text { kovalen } \\
\text { berdasarkan } \\
\text { beberapa sifat } \\
\text { fisika }\end{array}$ \\
\hline & $\begin{array}{l}\text { 3.6 Menerapkan } \\
\text { Teori Pasangan } \\
\text { Elektron Kulit } \\
\text { Valensi } \\
\text { (VSEPR) dan } \\
\text { Teori Domain } \\
\text { elektron dalam } \\
\text { menentukan }\end{array}$ & $\begin{array}{l}\text { 4.6 Membuat } \\
\text { model bentuk } \\
\text { molekul } \\
\text { dengan } \\
\text { menggunakan } \\
\text { bahan-bahan } \\
\text { yang ada di } \\
\text { lingkungan }\end{array}$ \\
\hline
\end{tabular}

\begin{tabular}{|c|c|c|}
\hline & bentuk molekul & $\begin{array}{l}\text { sekitar atau } \\
\text { perangkat } \\
\text { lunak } \\
\text { komputer }\end{array}$ \\
\hline & $\begin{array}{l}\text { 3.7 Menghubungkan } \\
\text { interaksi antar } \\
\text { ion, atom dan } \\
\text { molekul dengan } \\
\text { ifat fisika zat }\end{array}$ & $\begin{array}{l}\text { 4.7 Menerapkan } \\
\text { prinsip } \\
\text { interaksi } \\
\text { antar ion, } \\
\text { atom dan } \\
\text { molekul } \\
\text { dalam } \\
\text { menjelaskan } \\
\text { sifat-sifat } \\
\text { fisik zat di } \\
\text { sekitarnya }\end{array}$ \\
\hline $\begin{array}{l}\text { Larutan } \\
\text { elektrolit } \\
\text { dan } \\
\text { nonelektr } \\
\text { olit }\end{array}$ & $\begin{array}{l}\text { 3.8 Menganalisis } \\
\text { sifat larutan } \\
\text { berdasarkan } \\
\text { daya hantar } \\
\text { listriknya }\end{array}$ & $\begin{array}{l}\text { 4.8 Membedakan } \\
\text { daya hantar } \\
\text { listrik } \\
\text { berbagai } \\
\text { larutan } \\
\text { melalui } \\
\text { perancangan } \\
\text { dan } \\
\text { pelaksanaan } \\
\text { percobaan }\end{array}$ \\
\hline $\begin{array}{l}\text { Reaksi } \\
\text { Oksidasi } \\
\text { dan } \\
\text { Reduksi }\end{array}$ & $\begin{array}{l}\text { 3.9 } \text { Mengidentifikasi } \\
\text { reaksi reduksi } \\
\text { dan oksidasi } \\
\text { menggunakan } \\
\text { konsep bilangan } \\
\text { oksidasi unsur }\end{array}$ & $\begin{array}{l}\text { 4.9 Menganalisis } \\
\text { beberapa } \\
\text { reaksi } \\
\text { berdasarkan } \\
\text { perubahan } \\
\text { bilangan } \\
\text { oksidasi yang } \\
\text { diperoleh dari } \\
\text { data hasil } \\
\text { percobaan } \\
\text { dan/ atau } \\
\text { melalui } \\
\text { percobaan }\end{array}$ \\
\hline $\begin{array}{l}\text { Stoikiome } \\
\text { tri }\end{array}$ & $\begin{array}{l}3.10 \text { Menerapkan } \\
\text { hukum- } \\
\text { hukum dasar } \\
\text { kimia, konsep } \\
\text { massa } \\
\text { molekul } \\
\text { relatif, } \\
\text { persamaan } \\
\text { kimia, konsep } \\
\text { mol, dan } \\
\text { kadar zat } \\
\text { untuk } \\
\text { menyelesaika } \\
\text { n perhitungan } \\
\text { kimia }\end{array}$ & $\begin{array}{l}\text { 4.10 Menganalisis } \\
\text { data hasil } \\
\text { percobaan } \\
\text { menggunaka } \\
\text { n hukum- } \\
\text { hukum dasar } \\
\text { kimia } \\
\text { kuantitatif }\end{array}$ \\
\hline \multicolumn{3}{|c|}{ KELAS XI } \\
\hline $\begin{array}{l}\text { Senyawa } \\
\text { Hidrokar } \\
\text { bon dan } \\
\text { Minyak }\end{array}$ & $\begin{array}{l}\text { 3.1 Menganalisis } \\
\text { struktur dan } \\
\text { sifat senyawa } \\
\text { hidrokarbon }\end{array}$ & $\begin{array}{l}\text { 4.1 Membuat } \\
\text { model visual } \\
\text { berbagai } \\
\text { struktur }\end{array}$ \\
\hline
\end{tabular}




\begin{tabular}{|c|c|c|}
\hline \multirow[t]{3}{*}{ Bumi } & $\begin{array}{l}\text { berdasarkan } \\
\text { kekhasan } \\
\text { atom karbon } \\
\text { dan golongan } \\
\text { senyawanya }\end{array}$ & $\begin{array}{l}\text { molekul } \\
\text { hidrokarbon } \\
\text { yang memiliki } \\
\text { rumus molekul } \\
\text { yang sama }\end{array}$ \\
\hline & $\begin{array}{l}\text { 3.2 Menjelaskan } \\
\text { proses } \\
\text { pembentukan } \\
\text { fraksi-fraksi } \\
\text { minyak bumi, } \\
\text { teknik } \\
\text { pemisahan } \\
\text { serta } \\
\text { kegunaannya }\end{array}$ & \begin{tabular}{|l} 
4.2 \\
Menyajikan \\
karya tentang \\
proses \\
pembentukan \\
dan teknik \\
pemisahan \\
fraksi-fraksi \\
minyak bumi \\
beserta \\
kegunaannya
\end{tabular} \\
\hline & $\begin{array}{ll}3.3 & \\
& \text { Mengidentifik } \\
\text { asi reaksi } \\
\text { pembakaran } \\
\text { hidrokarbon } \\
\text { yang } \\
\text { sempurna dan } \\
\text { tidak } \\
\text { sempurna } \\
\text { serta sifat zat } \\
\text { hasil } \\
\text { pembakaran } \\
\left(\mathrm{CO}_{2}, \mathrm{CO},\right. \\
\text { partikulat } \\
\text { karbon) }\end{array}$ & \begin{tabular}{|l} 
4.3 \\
Menyusun \\
mengasan cara \\
mengatasi \\
dampak \\
pembakaran \\
senyawa \\
karbon \\
terhadap \\
lingkungan \\
dan kesehatan
\end{tabular} \\
\hline \multirow{2}{*}{$\begin{array}{l}\text { Thermoki } \\
\text { mia }\end{array}$} & $\begin{array}{l}\text { 3.4 Menjelaskan } \\
\text { konsep } \\
\text { perubahan } \\
\text { entalpi reaksi } \\
\text { pada tekanan } \\
\text { tetap dalam } \\
\text { persamaan } \\
\text { termokimia }\end{array}$ & $\begin{array}{l}\text { 4.4 Menyimpulkan } \\
\text { hasil analisis } \\
\text { data percobaan } \\
\text { termokima } \\
\text { pada tekanan } \\
\text { tetap }\end{array}$ \\
\hline & $\begin{array}{l}\text { 3.5 Menjelaskan } \\
\text { jenis entalpi } \\
\text { reaksi, hukum } \\
\text { Hess dan } \\
\text { konsep energi } \\
\text { ikatan }\end{array}$ & \begin{tabular}{|l}
4.5 \\
\\
Membandingk \\
an perubahan \\
entalpi \\
beberapa \\
reaksi \\
berdasarkan \\
data hasil \\
percobaan
\end{tabular} \\
\hline $\begin{array}{l}\text { Laju } \\
\text { Reaksi }\end{array}$ & $\begin{array}{l}\text { 3.6 Menjelaskan } \\
\text { faktor-faktor } \\
\text { yang } \\
\text { memengaruhi } \\
\text { laju reaksi } \\
\text { menggunakan } \\
\text { teori } \\
\text { tumbukan }\end{array}$ & \begin{tabular}{|l} 
4.6 Menyajikan \\
hasil \\
penelusuran \\
informasi cara- \\
cara \\
pengaturan \\
dan \\
penyimpanan \\
bahan untuk \\
mencegah \\
perubahan
\end{tabular} \\
\hline
\end{tabular}

\begin{tabular}{|c|c|c|}
\hline & & $\begin{array}{l}\text { fisika dan } \\
\text { kimia yang tak } \\
\text { terkendali }\end{array}$ \\
\hline & $\begin{array}{l}\text { 3.7 Menentukan } \\
\text { orde reaksi } \\
\text { dan tetapan } \\
\text { laju reaksi } \\
\text { berdasarkan } \\
\text { data hasil } \\
\text { percobaan }\end{array}$ & $\begin{array}{l}\text { 4.7 Merancang, } \\
\text { melakukan, } \\
\text { dan } \\
\text { menyimpulkan } \\
\text { serta } \\
\text { menyajikan } \\
\text { hasil } \\
\text { percobaan } \\
\text { faktor-faktor } \\
\text { yang } \\
\text { mempengaruhi } \\
\text { laju reaksi dan } \\
\text { orde reaksi }\end{array}$ \\
\hline \multirow[b]{2}{*}{$\begin{array}{l}\text { Kesetimb } \\
\text { angan } \\
\text { Kimia }\end{array}$} & $\begin{array}{l}\text { 3.8 Menjelaskan } \\
\text { reaksi } \\
\text { kesetimbanga } \\
\text { n di dalam } \\
\text { hubungan } \\
\text { antara } \\
\text { pereaksi dan } \\
\text { hasil reaksi } \\
\end{array}$ & $\begin{array}{l}\text { 4.8 } \text { Menyajikan } \\
\text { hasil } \\
\text { pengolahan } \\
\text { data untuk } \\
\text { menentukan } \\
\text { nilai tetapan } \\
\text { kesetimbangan } \\
\text { suatu reaksi } \\
\end{array}$ \\
\hline & $\begin{array}{l}\text { 3.9 Menganalisis } \\
\text { faktor-faktor } \\
\text { yang } \\
\text { mempengaruh } \\
\text { i pergeseran } \\
\text { arah } \\
\text { kesetimbanga } \\
\text { n dan } \\
\text { penerapannya } \\
\text { dalam industri }\end{array}$ & $\begin{array}{l}\text { 4.9 } \text { Merancang, } \\
\text { melakukan, } \\
\text { dan } \\
\text { menyimpulka } \\
\text { n serta } \\
\text { menyajikan } \\
\text { hasil } \\
\text { percobaan } \\
\text { faktor-faktor } \\
\text { yang } \\
\text { mempengaru } \\
\text { hi pergeseran } \\
\text { arah } \\
\text { kesetimbanga } \\
\mathrm{n}\end{array}$ \\
\hline \multirow[t]{2}{*}{$\begin{array}{l}\text { Asam } \\
\text { Dan Basa }\end{array}$} & $\begin{array}{l}\text { 3.10 Menjelaskan } \\
\text { konsep asam } \\
\text { dan basa serta } \\
\text { kekuatannya } \\
\text { dan } \\
\text { kesetimbanga } \\
\mathrm{n} \\
\text { pengionannya } \\
\text { dalam larutan }\end{array}$ & $\begin{array}{l}\text { 4.10 Menganalisis } \\
\text { trayek } \\
\text { perubahan } \\
\text { pH beberapa } \\
\text { indikator } \\
\text { yang } \\
\text { diekstrak } \\
\text { dari bahan } \\
\text { alam melalui } \\
\text { percobaan }\end{array}$ \\
\hline & $\begin{array}{l}\text { 3.13 Menganalisis } \\
\text { data hasil } \\
\text { berbagai jenis } \\
\text { titrasi asam- } \\
\text { basa }\end{array}$ & 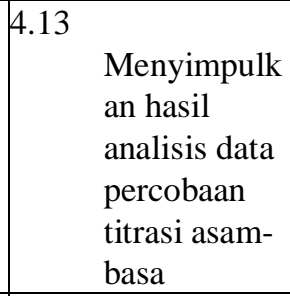 \\
\hline Hidrolisis & $\begin{array}{l}3.11 \text { Menganalisis } \\
\text { kesetimbanga }\end{array}$ & $\begin{array}{r}4.11 \text { Melaporkan } \\
\text { percobaan }\end{array}$ \\
\hline
\end{tabular}




\begin{tabular}{|c|c|c|}
\hline & $\begin{array}{l}\mathrm{n} \text { ion dalam } \\
\text { larutan garam } \\
\text { dan } \\
\text { menghubungk } \\
\text { an } p \mathrm{H} \text {-nya }\end{array}$ & $\begin{array}{l}\text { tentang sifat } \\
\text { asam basa } \\
\text { berbagai } \\
\text { larutan } \\
\text { garam }\end{array}$ \\
\hline $\begin{array}{l}\text { Larutan } \\
\text { Penyangg } \\
\text { a }\end{array}$ & $\begin{array}{l}\text { 3.12 Menjelaskan } \\
\text { prinsip kerja, } \\
\text { perhitungan } \\
\text { pH, dan peran } \\
\text { larutan } \\
\text { penyangga } \\
\text { dalam tubuh } \\
\text { makhluk } \\
\text { hidup }\end{array}$ & \begin{tabular}{|l} 
4.12 Membuat \\
larutan \\
penyangga \\
dengan $p \mathrm{H}$ \\
tertentu
\end{tabular} \\
\hline Koloid & $\begin{array}{ll}3.14 & \\
\text { Mengelompok } \\
\text { kan berbagai } \\
\text { tipe sistem } \\
\text { koloid, dan } \\
\text { menjelaskan } \\
\text { kegunaan } \\
\text { koloid dalam } \\
\text { kehidupan } \\
\text { berdasarkan } \\
\text { sifat-sifatnya }\end{array}$ & \begin{tabular}{|l} 
4.14 Membuat \\
makanan \\
atau produk \\
lain yang \\
berupa \\
koloid atau \\
melibatkan \\
prinsip \\
koloid
\end{tabular} \\
\hline \multicolumn{3}{|c|}{ KELAS XII } \\
\hline \multirow[t]{2}{*}{$\begin{array}{l}\text { Sifat } \\
\text { Koligatif } \\
\text { Larutan }\end{array}$} & $\begin{array}{l}\text { 3.1 Menganalisis } \\
\text { fenomena sifat } \\
\text { koligatif } \\
\text { larutan } \\
\text { (penurunan } \\
\text { tekanan uap } \\
\text { jenuh, kenaikan } \\
\text { titik didih, } \\
\text { penurunan titik } \\
\text { beku, dan } \\
\text { tekanan } \\
\text { osmosis) }\end{array}$ & \begin{tabular}{|l} 
4.1 Menyajikan \\
hasil \\
penelusuran \\
informasi \\
tentang \\
kegunaan \\
prinsip sifat \\
koligatif \\
larutan dalam \\
kehidupan \\
sehari-hari
\end{tabular} \\
\hline & $\begin{array}{l}\text { 3.2 Membedakan } \\
\text { sifat koligatif } \\
\text { larutan } \\
\text { elektrolit dan } \\
\text { larutan } \\
\text { nonelektrolit }\end{array}$ & \begin{tabular}{|l} 
4.2 \\
Menganalisis \\
data percobaan \\
untuk \\
menentukan \\
derajat \\
pengionan
\end{tabular} \\
\hline \multirow[t]{2}{*}{$\begin{array}{l}\text { Redoks } \\
\text { dan Sel } \\
\text { Elektroki } \\
\text { mia }\end{array}$} & $\begin{array}{c}\text { 3.3 Menyetarakan } \\
\text { persamaan } \\
\text { reaksi redoks }\end{array}$ & \begin{tabular}{|l} 
4.3 \\
Menentukan \\
urutan \\
kekuatan \\
pengoksidasi \\
atau pereduksi \\
berdasarkan \\
data hasil \\
percobaan
\end{tabular} \\
\hline & $\begin{array}{c}\text { 3.4 Menganalisis } \\
\text { proses yang } \\
\text { terjadi dalam } \\
\text { sel Volta dan } \\
\text { menjelaskan }\end{array}$ & $\begin{array}{l}\text { 4.4 Merancang sel } \\
\text { Volta dengan } \\
\text { mengunakan } \\
\text { bahan di } \\
\text { sekitar }\end{array}$ \\
\hline
\end{tabular}

\begin{tabular}{|c|c|c|}
\hline & kegunaannya & \\
\hline & $\begin{array}{l}\text { 3.5 Menganalisis } \\
\text { faktor-faktor } \\
\text { yang } \\
\text { mempengaruhi } \\
\text { terjadinya } \\
\text { korosi dan cara } \\
\text { mengatasinya }\end{array}$ & $\begin{array}{l}4.5 \text { Mengajukan } \\
\text { gagasan untuk } \\
\text { mencegah dan } \\
\text { mengatasi } \\
\text { terjadinya } \\
\text { korosi }\end{array}$ \\
\hline & $\begin{array}{l}\text { 3.6 Menerapkan } \\
\text { stoikiometri } \\
\text { reaksi redoks } \\
\text { dan hukum } \\
\text { Faraday untuk } \\
\text { menghitung } \\
\text { besaran- } \\
\text { besaran yang } \\
\text { terkait sel } \\
\text { elektrolisis } \\
\end{array}$ & $\begin{array}{l}\text { 4.6 Menyajikan } \\
\text { rancangan } \\
\text { prosedur } \\
\text { penyepuhan } \\
\text { benda dari } \\
\text { logam dengan } \\
\text { ketebalan } \\
\text { lapisan dan } \\
\text { luas tertentu }\end{array}$ \\
\hline \multirow{2}{*}{$\begin{array}{l}\text { Kimia } \\
\text { Unsur }\end{array}$} & $\begin{array}{l}\text { 3.7 Menganalisis } \\
\text { kelimpahan, } \\
\text { kecenderungan } \\
\text { sifat fisika dan } \\
\text { kimia, manfaat, } \\
\text { dan proses } \\
\text { pembuatan } \\
\text { unsur-unsur } \\
\text { golongan } \\
\text { utama (gas } \\
\text { mulia, halogen, } \\
\text { alkali, dan } \\
\text { alkali tanah) }\end{array}$ & $\begin{array}{l}\text { 4.7 } \text { Menyajikan } \\
\text { data hasil } \\
\text { penelusuran } \\
\text { informasi sifat } \\
\text { dan pembuatan } \\
\text { unsur-unsur } \\
\text { golongan } \\
\text { utama } \\
\text { (halogen, } \\
\text { alkali, dan } \\
\text { alkali tanah) }\end{array}$ \\
\hline & $\begin{array}{l}\text { 3.8 Menganalisis } \\
\text { kelimpahan, } \\
\text { kecenderungan } \\
\text { sifat fisika dan } \\
\text { kimia, manfaat, } \\
\text { dan proses } \\
\text { pembuatan } \\
\text { unsur-unsur } \\
\text { periode } 3 \text { dan } \\
\text { golongan } \\
\text { transisi } \\
\text { (periode 4) } \\
\end{array}$ & $\begin{array}{l}\text { 4.8 Menyajikan } \\
\text { data hasil } \\
\text { penelusuran } \\
\text { informasi sifat } \\
\text { dan pembuatan } \\
\text { unsur-unsur } \\
\text { Periode } 3 \text { dan } \\
\text { unsur } \\
\text { golongan } \\
\text { transisi } \\
\text { (periode 4) }\end{array}$ \\
\hline $\begin{array}{l}\text { Senyawa } \\
\text { Turunan } \\
\text { Alkana }\end{array}$ & $\begin{array}{l}\text { 3.9 Menganalisis } \\
\text { struktur, } \\
\text { tatanama, sifat, } \\
\text { sintesis, dan } \\
\text { kegunaan } \\
\text { senyawa } \\
\text { karbon }\end{array}$ & $\begin{array}{l}\text { 4.9 Menyajikan } \\
\text { rancangan } \\
\text { percobaan } \\
\text { sintesis } \\
\text { senyawa } \\
\text { karbon, } \\
\text { identifikasi } \\
\text { gugus fungsi } \\
\text { dan/atau } \\
\text { penafsiran data } \\
\text { spektrum } \\
\text { inframerah } \\
\text { (IR) } \\
\end{array}$ \\
\hline $\begin{array}{l}\text { Benzena } \\
\text { dan }\end{array}$ & $\begin{array}{r}3.10 \text { Menganalisis } \\
\text { struktur, tata }\end{array}$ & $\begin{array}{c}\text { 4.10 Menyajikan } \\
\text { hasil }\end{array}$ \\
\hline
\end{tabular}




\begin{tabular}{|c|c|c|}
\hline $\begin{array}{l}\text { Turunan } \\
\text { nya }\end{array}$ & $\begin{array}{l}\text { nama, sifat, } \\
\text { dan kegunaan } \\
\text { benzena dan } \\
\text { turunannya }\end{array}$ & $\begin{array}{l}\text { penelusuran } \\
\text { informasi } \\
\text { beberapa } \\
\text { turunan } \\
\text { benzena } \\
\text { yang } \\
\text { berbahaya } \\
\text { dan tidak } \\
\text { berbahaya }\end{array}$ \\
\hline $\begin{array}{l}\text { Makromo } \\
\text { lekul }\end{array}$ & $\begin{array}{l}\text { 3.11 Menganalisis } \\
\text { struktur, tata } \\
\text { nama, sifat } \\
\text { dan } \\
\text { penggolongan } \\
\text { makromolekul }\end{array}$ & \begin{tabular}{|l} 
4.11 \\
Menganalisis \\
hasil \\
penelusuran \\
informasi \\
mengenai \\
pembuatan \\
dan dampak \\
suatu produk \\
dari \\
makromolek \\
ul
\end{tabular} \\
\hline
\end{tabular}

3. Persentase Muatan Kurikulum Pendidikan Kimia di Perguruan Tinggi yang Masuk dalam Muatan Kurikulum Kimia Berbasis K-13 di Sekolah Menengah Atas.

Analisis relevansi muatan kurikulum Kimia di Perguruan Tinggi dengan muatan kurikulum Kimia SMA berbasis K-13 dilakukan dengan membuat matriks. Kerelevanan yang dimaksud yaitu kesesuaian muatan profesional kurikulum Pendidikan Kimia dengan muatan kurikulum Kimia SMA berbasis K-13 (vertikal) dan kesinambungan muatan kurikulum Kimia SMA berbasis K-13 dengan muatan profesional kurikulum Pendidikan Kimia FMIPA UNM (Horisontal). Kerelevanan ditentukan dengan memberi 1 poin untuk setiap kesesuaian dan kesinambungan antara muatan profesioanl kurikulum Pendidikan Kimia FMIPA UNM dan muatan kurikulum Kimia SMA berbasis K-13.

a. Kesesuaian Muatan Profesional Kurikulum Pendidikan Kimia FMIPA UNM dan muatan kurikulum Kimia SMA berbasis K-13
Hasil analisis menunjukan bahwa ada 19 mata kuliah yang memiliki kesesuaian dengan materi pokok Kimia SMA. Mata kuliah tersebut yaitu Kimia Dasar, Kimia Dasar Lanjut, Kimia Fisik I, Kimia Anorganik I, Kimia Organik I, Kimia Fisik II, Kimia Anorganik Fisik, Kimia Lingkungan, Kimia Analitik, Kimia Organik II, Kimia Anorganik II, Kimia Organik III, Ikatan Kimia, Pengelolaan Laboratorium Kimia, Kimia Analitik II, Biokimia, Kimia Analisis Instrumen, Kimia Inti dan Radiokimia, dan Kimia Pangan. Berdasarkan hasil analisis, persentase kesesuaian muatan kurikulum Kimia Pendidikan Kimia dengan muatan kurikulum Kimia SMA Berbasisi K-13 dapat di lihat pada Tabel 4.22

Tabel 4.22 Persentase Kesesuaian Muatan Kurikulum Kimia Pendidikan Kimia dengan Muatan Kurikulum Kimia SMA Berbasis K-13

\begin{tabular}{|c|c|c|}
\hline Mata Kuliah & $\begin{array}{l}\text { Frekuensi } \\
\text { (F) }\end{array}$ & $\begin{array}{c}\text { Persentase } \\
(\%)\end{array}$ \\
\hline Kimia Dasar & 11 & 55 \\
\hline $\begin{array}{l}\text { Kimia Dasar } \\
\text { Lanjut }\end{array}$ & 10 & 50 \\
\hline Kimia Fisika I & 7 & 35 \\
\hline Kimia Anorganik I & 5 & 25 \\
\hline Kimia Organik I & \multirow{4}{*}{4} & \multirow{4}{*}{20} \\
\hline Kimia Fisika II & & \\
\hline $\begin{array}{l}\text { Kimia Anorganik } \\
\text { Fisik }\end{array}$ & & \\
\hline Kimia Lingkungan & & \\
\hline Kimia Analitik I & \multirow{2}{*}{3} & \multirow{2}{*}{15} \\
\hline Kimia Organik II & & \\
\hline $\begin{array}{l}\text { Kimia Anorganik } \\
\text { II }\end{array}$ & \multirow{3}{*}{2} & \multirow{3}{*}{10} \\
\hline Kimia Organik III & & \\
\hline Ikatan Kimia & & \\
\hline $\begin{array}{l}\text { Pengelolaan } \\
\text { Laboratorium } \\
\text { Kimia } \\
\end{array}$ & \multirow{6}{*}{1} & \multirow{6}{*}{5} \\
\hline Kimia Analitik II & & \\
\hline Biokimia & & \\
\hline $\begin{array}{l}\text { Kimia Analisis } \\
\text { Instrumen }\end{array}$ & & \\
\hline $\begin{array}{l}\text { Kimia Inti dan } \\
\text { radiokimia }\end{array}$ & & \\
\hline Kimia Pangan & & \\
\hline
\end{tabular}


b. Kesinambungan Muatan Kurikulum Kimia SMA Berbasis K-13 dengan Muatan Profesional Kurikulum Pendidikan Kimia FMIPA UNM.

Selain kesesuaian muatan kurikulum Kimia Pendidikan Kimia FMIPA UNM dengan muatan kurikulum Kimia SMA berbasis K-13, kerelevanan juga ditinjau dari berkesinambungannya muatan kurikulum Kimia SMA berbasis K13 dengan muatan kurikulum Kimia Pendidikan Kimia FMIPA UNM. Persentase Kesinambungan muatan kurikulum Kimia SMA berbasis K-13 dengan muatan kurikulum Kimia Pendidikan Kimia FMIPA UNM dapat dilihat pada Tabel 4.23

Tabel 4.23 Kesinambungan Muatan

Kurikulum Kimia SMA Berbasis K-13 dengan Muatan Kurikulum Kimia Pendidikan Kimia FMIPA UNM

\begin{tabular}{|c|c|c|c|}
\hline $\begin{array}{l}\text { Materi } \\
\text { Pokok }\end{array}$ & $\begin{array}{l}\text { Mata Kuliah yang } \\
\text { Berkesinambungan }\end{array}$ & $\begin{array}{l}\text { Frek } \\
\text { uensi } \\
(\mathbf{F})\end{array}$ & $\begin{array}{c}\text { Perse } \\
\text { ntase } \\
(\%)\end{array}$ \\
\hline $\begin{array}{l}\text { Asam dan } \\
\text { Basa }\end{array}$ & $\begin{array}{l}\text { Kimia Dasar, Kimia } \\
\text { Dasar Lanjut, Kimia } \\
\text { organik I, Kimia } \\
\text { Anorganik I, Kimia } \\
\text { Analitik I, Kimia Fisik } \\
\text { I, Kimia Fisik II dan } \\
\text { Kimia Anorganik Fisik }\end{array}$ & 8 & 40 \\
\hline $\begin{array}{l}\text { Ikatan } \\
\text { Kimia }\end{array}$ & $\begin{array}{l}\text { Kimia Dasar, Kimia } \\
\text { Anorganik I, Kimia } \\
\text { Anorganik II, Kimia } \\
\text { Anorganik Fisik dan } \\
\text { Ikatan Kimia }\end{array}$ & \multirow{4}{*}{5} & \multirow{4}{*}{25} \\
\hline $\begin{array}{l}\text { Senyawa } \\
\text { Hidrokar } \\
\text { bon dan } \\
\text { Minyak } \\
\text { Bumi }\end{array}$ & $\begin{array}{l}\text { Kimia Dasar, Kimia } \\
\text { Organik I, Kimia } \\
\text { Organik II, Kimia } \\
\text { Analitik II dan Kimia } \\
\text { Lingkungan }\end{array}$ & & \\
\hline $\begin{array}{l}\text { Redoks } \\
\text { dan Sel } \\
\text { Elektroki } \\
\text { mia }\end{array}$ & $\begin{array}{l}\text { Kimia Dasar, Kimia } \\
\text { Dasar Lanjut, Kimia } \\
\text { Fisik I, Kimia Fisik II } \\
\text { dan Kimia Anorganik } \\
\text { Fisik }\end{array}$ & & \\
\hline $\begin{array}{l}\text { Makromo } \\
\text { lekul }\end{array}$ & $\begin{array}{l}\text { Kimia Dasar, Kimia } \\
\text { Organik II, Biokimia, } \\
\text { Kimia Pangan, dan } \\
\text { Kimia Lingkungan }\end{array}$ & & \\
\hline
\end{tabular}

\begin{tabular}{|c|c|c|c|}
\hline $\begin{array}{l}\text { Kimia } \\
\text { Unsur }\end{array}$ & $\begin{array}{l}\text { Kimia Dasar Lanjut, } \\
\text { Kimia Anorganik I, } \\
\text { Kimia Anorganik II } \\
\text { dan Kimia Anorganik } \\
\text { Fisik, danKimia dan } \\
\text { Radiokimia }\end{array}$ & & \\
\hline $\begin{array}{l}\text { Reaksi } \\
\text { Oksidasi } \\
\text { dan } \\
\text { Reduksi }\end{array}$ & $\begin{array}{l}\text { Kimia Dasar, Kimia } \\
\text { Anorganik I, Kimia } \\
\text { Analitik I, dan Kimia } \\
\text { Organik III }\end{array}$ & \multirow{3}{*}{4} & \multirow{3}{*}{20} \\
\hline $\begin{array}{l}\text { Senyawa } \\
\text { Turunan } \\
\text { Alkana }\end{array}$ & $\begin{array}{l}\text { Kimia Dasar, Kimia } \\
\text { Organik I, Kimia } \\
\text { Organik III dan Kimia } \\
\text { Analisis Instrumen }\end{array}$ & & \\
\hline $\begin{array}{l}\text { Struktur } \\
\text { Atom dan } \\
\text { Tabel } \\
\text { Periodik } \\
\end{array}$ & $\begin{array}{l}\text { Kimia Dasar, Kimia } \\
\text { Anorganik I dan Ikatan } \\
\text { Kimia }\end{array}$ & & \\
\hline $\begin{array}{l}\text { Stoikiom } \\
\text { etri }\end{array}$ & $\begin{array}{l}\text { Kimia Dasar, Kimia } \\
\text { Fisik I dan Kimia } \\
\text { Analitik I }\end{array}$ & \multirow{4}{*}{3} & \multirow{4}{*}{15} \\
\hline $\begin{array}{l}\text { Laju } \\
\text { Reaksi }\end{array}$ & $\begin{array}{l}\text { Kimia Dasar, Kimia } \\
\text { Dasar Lanjut dan } \\
\text { Kimia Fisik II } \\
\end{array}$ & & \\
\hline $\begin{array}{l}\text { Benzena } \\
\text { dan } \\
\text { Turunann } \\
\text { ya }\end{array}$ & $\begin{array}{l}\text { Kimia Organik I, } \\
\text { Kimia Organik II dan } \\
\text { Kimia Lingkungan }\end{array}$ & & \\
\hline $\begin{array}{l}\text { Hakikat } \\
\text { dan } \\
\text { Peranan } \\
\text { Kimia } \\
\text { dalam } \\
\text { Kehidupa } \\
\text { n serta } \\
\text { Metode } \\
\text { Ilmiah }\end{array}$ & $\begin{array}{l}\text { Pengelolaan } \\
\text { Laboratorium Kimia } \\
\text { dan Kimia Lingkungan }\end{array}$ & & \\
\hline $\begin{array}{l}\text { Larutan } \\
\text { elektrolit } \\
\text { dan } \\
\text { nonelektr } \\
\text { olit }\end{array}$ & $\begin{array}{l}\text { Kimia Dasar Lanjut } \\
\text { dan Kimia Fisik II }\end{array}$ & \multirow{6}{*}{2} & \multirow{6}{*}{10} \\
\hline $\begin{array}{l}\text { Termoki } \\
\text { mia }\end{array}$ & $\begin{array}{l}\text { Kimia Dasar dan Kimia } \\
\text { Fisik I }\end{array}$ & & \\
\hline $\begin{array}{l}\text { Kesetimb } \\
\text { angan } \\
\text { Kimia }\end{array}$ & $\begin{array}{l}\text { Kimia Dasar Lanjut } \\
\text { dan Kimia Fisik I }\end{array}$ & & \\
\hline Hidrolisis & $\begin{array}{l}\text { Kimia Dasar Lanjut } \\
\text { dan Kimia Fisik I }\end{array}$ & & \\
\hline $\begin{array}{l}\text { Sifat } \\
\text { Koligatif } \\
\text { Larutan }\end{array}$ & $\begin{array}{l}\text { Kimia Dasar Lanjut } \\
\text { dan Kimia Fisik I }\end{array}$ & & \\
\hline $\begin{array}{l}\text { Larutan } \\
\text { Penyangg } \\
\text { a }\end{array}$ & Kimia Dasar Lanjut & & \\
\hline Koloid & Kimia Dasar Lanjut & 1 & 5 \\
\hline
\end{tabular}


umum, maka diperoleh persentase kesesuaian muatan profesional Kurikulum Pendidikan Kimia FMIPA UNM terhadap materi pokok Kimia SMA sebesar 95\% relevan. Hal ini disebabkan karena dari 20 mata kuliah, ada 19 mata kuliah yang memiliki kesesuaian dengan materi pokok SMA walaupun persentase kesesuaian mata kuliah bervariasi, sedangkan untuk persentase kesinambungan materi pokok Kimia SMA terhadap mata kuliah sebesar $100 \%$ relevan, hal ini disebabkan karena keseluruhan materi pokok Kimia SMA (20 materi pokok) berkesinambungan terhadap mata kuliah Kimia Pendidikan Kimia FMIPA UNM walaupun persentase kesinambungan materi pokok bervariasi. Berdasarkan kriteria tingkat kerelevanan Kurikulum pada Tabel 3.1 diperoleh kerelevanan dengan kategori sangat tinggi untuk kesesuaian mata kuliah terhadap materi pokok dan kesinambungan materi pokok terhadap mata kuliah.

4. Persentase Muatan Profesional Kurikulum Pendidikan Kimia di Perguruan Tinggi yang Termasuk Materi Pengayaan dalam Muatan Kurikulum Kimia Berbasis K-13 di Sekolah Menengah Atas.

Berdasarkan matriks analisis muatan Kurikulum Kimia di Perguruan Tinggi dengan muatan Kurikulum Kimia SMA berbasis K-13, ada satu mata kuliah yang termasuk materi pengayaan muatan Kurikulum Kimia SMA yaitu Mata Kuliah Kimia Matematika yang dapat di lihat pada Tabel 4.24.

Tabel 4.24 Muatan Profesional Kurikulum Pendidikan Kimia FMIPA UNM yang termasuk materi pengayaan dalam Muatan Kurikulum Kimia SMA Berbasis K-13.

\begin{tabular}{|c|c|c|}
\hline $\begin{array}{c}\text { Mata } \\
\text { Kuliah }\end{array}$ & $\begin{array}{c}\text { Frekuensi } \\
(\text { F })\end{array}$ & $\begin{array}{c}\text { Persentase } \\
(\%)\end{array}$ \\
\hline
\end{tabular}

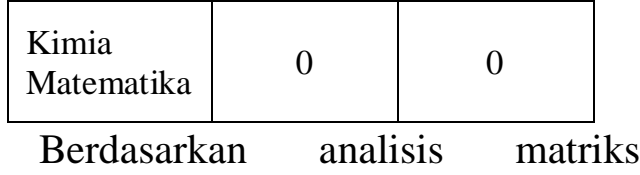

muatan Kurikulum pada Tabel 4.24 diperoleh dua mata kuliah yang termasuk materi pengayaan dalam muatan Kurikulum Kimia SMA yaitu Mata Kuliah Kimia Matematika. Tujuan mata kuliah Kimia Matematika yaitu mahasiswa mampu menerapkan/menganalisis konsep Matematika dalam memecahkan masalah kimia.

Dari hasil analisis kritis terlihat bahwa Kimia Matematika termasuk materi pengayaan dalam muatan Kurikulum Kimia SMA, karena pada mata kuliah Kimia Matematika memuat kemampuan pemecahan masalah, kemampuan dalam berpikir logis, dan berpikir secara skematis yang dibutuhkan untuk memahami beberapa kompetensi pada muatan Kurikulum Kimia SMA berbasis K-13.

Jika ditinjau dari kerelevanan (kesesuaian) secara umum, maka diperoleh persentase muatan profesional Kurikulum Pendidikan Kimia di Perguruan Tinggi yang termasuk materi pengayaan dalam muatan Kurikulum Kimia SMA berbasis K-13 adalah sebesar 5\%. Hal ini disebabkan karena dari 20 mata kuliah, hanya 1 mata kuliah yang termasuk materi pengayaan untuk membantu memahami materi pokok SMA.

\section{KESIMPULAN}

Berdasarkan hasil penelitian dan pembahasan, dapat dikemukakan simpulan sebagai berikut: (1) Muatan kurikulum Program Studi Pendidikan Kimia Perguruan Tinggi di Jurusan Kimia FMIPA UNM terdiri dari mata kuliah wajib dan mata kuliah pilihan dengan jumlah SKS yang wajib dilulusi minimal 144 SKS (mata kuliah wajib 136 SKS dan mata 
kuliah pilihan minimal 8 SKS), dimana muatan kurikulum Kimia terdiri dari 20 mata kuliah yang wajib diprogram oleh mahasiswa Pendidikan Kimia dari semester I sampai semester VIII; (2) Muatan kurikulum Kimia SMA berbasis K-13 memiliki dua Kompetensi Dasar yaitu Kompetensi Dasar Pengetahuan dan Kompetensi Dasar Keterampilan, dari kompetensi tersebut terangkum dalam 20 materi pokok Kimia mulai dari kelas $\mathrm{X}$ sampai kelas XII; (3) Persentase kesesuaian muatan profesional Kurikulum Pendidikan Kimia FMIPA UNM terhadap materi pokok Kimia SMA sebesar 95\%, hal ini terlihat dari 20 mata kuliah, terdapat 19 mata kuliah yang memiliki kesesuaian materi dengan materi pokok SMA, dan untuk persentase kesinambungan materi pokok Kimia SMA dengan mata kuliah sebesar 100\%, hal ini terlihat dari keseluruhan materi pokok Kimia SMA pada 20 materi pokok semuanya berkesinambungan dengan mata kuliah Kimia Pendidikan Kimia FMIPA UNM; (4) Persentase muatan profesional Kurikulum Pendidikan Kimia di Perguruan Tinggi yang termasuk materi dalam muatan Kurikulum Kimia SMA berbasis K-13 adalah sebesar 5\%. Hal ini terlihat dari 20 mata kuliah, terdapat 1 mata kuliah yang termasuk materi pengayaan untuk memahami materi pokok kimia SMA yaitu mata kuliah Kimia Matematika.

\section{DAFTAR PUSTAKA}

Baswedan, Anies R. 2014. Gawat Darurat Pendidikan di Indonesia. Makalah disajikan dalam Silaturahmi Kementrian dengan Kepala Dinas, Jakarta, 1 Desember.

Bustan. 1 Agustus, 2013. UNM: 52 Tahun Mencerdaskan Bangsa. Tribun Timur.
Hamalik, Oemar. 2013. Dasar-Dasar pengembangan Kurikulum. Bandung: PT. Remaja Rosdakarya. Hussain, Afzaal, Ashiq Hussain Dogar, \& Muhammad Azeem. 2011. Evaluation of Curriculum Development Process. European Social Sciences Research Journal. Vol. 1 No. 14.

Juangsih, Juju. 2014. Peran LPTK dalam Menghasilkan Guru Profesional. Wahana Didaktika,Vol. 12 No. 2 Mei 2014 : 72-83

Kemendikbud. 2013. Kurikulum 2013, Kompetensi Dasar SMA/MA. Jakarta.

Kemendikbud. 2014. Buku Kurikulum Pendidikan Tinggi. Jakarta: Direktorat Jenderal Pembelajaran dan Kemahasiswaan.

Lozano, Rodrigo \& Mary Katherine Watson. 2013. Chemistry Education for Sustainability: Assessing the Chemistry Curricula at Cardiff University. Educacion Quimica, Vol. 24. No. 2. ISSNE 1870-8404.

Salsabilla, Farri. 2013. Relevansi Kurikulum Jurusan Kurikulum dan Teknologi Pendidikan dengan Dunia Kerja (Studi Kasus Guru Tik, Dinas Pendidikan, dan Lembaga Diklat). Semarang: Jurusan Kurikulum Dan Teknologi Pendidikan Fakultas Ilmu Pendidikan Universitas Negeri Semarang.

Sukiman. 2015. Pengembangan Kurikulum Perguruan Tinggi. Bandung: PT. Remaja Rosdakarya.

Syafaruddin. 2002. Manajemen Mutu Terpadu dalam Pendidikan Konsep, Strategi, dan Syah, Muhibbin. 2005. Psikologi Pendidikan dengan Pendekatan Baru, Bandung: PT. Remaja Rosdakarya. 
Syahrial, M. Nazar, Fauziah, Riza Zulyani dan Emidiati. 2010. Relevansi Kurikulum Program Studi Pendidikan Kimia FKIP Usyiah dengan Kompetensi Guru Kimia di SMA dan MA. Prosiding Evaluasi Pendidikan dan Penelitian, 168172.

Undang-Undang Nomor 14 Tahun 2005 Tentang Guru dan Dosen. Sinar Grafika: Jakarta, 2006.

Undang-Undang Nomor 19 Tahun 2005

Tentang Standar Nasional Pendidikan. Sinar Grafika: Jakarta, 2006.

Undang-Undang Republik Indonesia Nomor 20 Tahun 2003 Tentang Sistem Pendidikan Nasional. Jakarta.

Usman, M. Uzer. 2003. Menjadi Guru Profesional. Bandung: PT. Remaja Rosdakarya. 